Petr Dobrovolný

\title{
Navrhování budov s ohledem na recyklaci
}

Klíčová slova: Stavební demoliční odpad; Recyklace; Downcycling.

Kontakt: petr@dobrovolny-architekt.cz

Školitel: Ivana Žabičková

Tematický okruh: Architektura

\section{Recycling-Aware Building Design}

The paper focuses on recycling in the building industry, placing emphasis on load-bearing building structures. Current practice is taken as the starting point, namely the processes of demolition, material separation and further processing. Based on collected data, the paper determines the key principles for good building design that takes into account future recycling. 
Tento příspěvek se zabývá problematikou recyklace ve stavebnictví s důrazem na nosné konstrukce staveb. Východiskem je popis stávající praxe - především používaných postupo̊ demolice, třídění materiálů a jejich zpracování. Na základě sebraných údajů stanovuje základní zásady dobrého navrhování budov s ohledem na budoucí recyklaci.

První část příspěvku se věnuje historickému kontextu a popisu současného stavu. Jsou popsány hlavní materiálové toky ve stavebnictví. Pomocí statistických údajů jsou ukázány nejpoužívanější stavební materiály, druh a množství vyprodukovaných stavebních odpadi̊ a druh a množství vyprodukovaných recyklátů. Budou srovnána domácí data se zahraničními a vyvozeny základní vývojové trendy.

V další části budou souhrnně popsány obvyklé postupy demolice objektů a členění stavebních odpadů dle vyhlášky MŽP č. 381/2001 Sb. Nejpoužívanější stavební materiály (beton, cihly a keramika, kovy a slitiny kovů, dřevo) budou pojednány podrobněji z hlediska způsobu demolice konstrukcí, zpracování odpadu a možností jeho dalšího využití. Zvláštní pozornost bude věnována dalším přírodním stavebním materiálům, např. nepálené hlíně a slámě, jejichž podíl na stavebním trhu je zatím zanedbatelný, ale které z hlediska využití stavebních odpadů nabízejí zajímavé možnosti.

Návrh nosné konstrukce budovy dělí od jejího zániku obvykle desítky nebo stovky let, a proto je obtížné odhadnout budoucí technické a ekonomické podmínky. Přesto je žádoucí se na základě sebraných údajů o současných používaných metodách recyklace, historických postupech, případně na základě srovnání s jinými průmyslovými odvětvími pokusit o stanovení základních principů dobrého navrhování pro recyklaci. Budou se týkat jak materiálového, tak konstrukčního řešení stavby. Důraz by přitom měl být kladen zejména na postupy, které umožňují mnohonásobné opakování recyklace a při kterých nedochází k poklesu kvality materiálu.

\section{ZKRÁCENÝ SOUPIS ZDROJU゚}

ČESKO. Zákon č. 185/2001 Sb. O odpadech a změně některých dalších zákonů. [cit. 2015-05-24]. <https://portal.gov.cz/app/zakony/download?idBiblio $=51365 \& n r=185 \sim 2 F 2001 \sim 20 S b . \& f t=p d f>$.

ČESKO. Vyhláška MŽP č. 381/2001 Sb. kterou se stanoví Katalog odpadů, Seznam nebezpečných odpadů a seznamy odpadů a států pro účely vývozu, dovozu a tranzitu odpadů a postup při udělování souhlasu k vývozu, dovozu a tranzitu odpadů (Katalog odpadů). [cit. 2015-05-24]. <https://portal.gov.cz/app/zakony/download?idBiblio=51786\&nr=381 2F2001 20Sb. \& ft $=p d f>$. 
ŠKOPÁN, Miroslav. Recyklované materiály - stav a cesty k dalšímu rozvoji. In ŠKOPÁN M. (edit.). Recycling 2014. Možnosti a perspektivy recyklace stavebních odpadů jako zdroje plnohodnotných surovin. Brno : VUT Brno, 2014. 145 s. ISBN 978-80-214-4866-7.)

ŠTĚRBA M. - HENKOVÁ S. - ČECH D. - VENKRBEC V. Demolice stavebních objektů. [cit. 2014-12-28]. <http://www.silnice-zeleznice.cz/clanek/ demolice-stavebnich-objektu/>.

VYTLAČILOVÁ Vladimíra, P., Recyklace ve stavební výrobě. 1. vyd. Praha : ČVUT v Praze, Fakulta stavební, 2012. 116 s. ISBN 978-80-01-05184-9

\section{FOTOGRAFIE}

[1] APB Plzeň. w_668.h_503.q_100. [fotografie]. Zařízení používaná při demolici betonových a železobetonových konstrukcí. [online]. Dostupné z: http://www.apb-plzen.cz/technika-pro-demolicni-prace. Formát: 503 x 668.

[2] Recyklační linka s drtičem Resta 900x600 s třídičem Resta TH2 1600x4000/2. In: Resta [online]. (c) 2014 RESTA s.r.o. [vid. 29.12.2014]. Dostupné z: http://www.resta.cz

[3] Příklad demolice dřevostavby a přípravy dřevěných prvků k novému využití. In: EPA [online]. (c) 2015 EPA. [vid. 2.1.2015]. Dostupné z: http:// www.epa.gov/region9/greenbuilding/pdfs/DesignForDeconstrManual. pdf

[4] DOBROVOLNÝ, Petr. Vzorky materiálu z cihelného recyklátu - bez dalších príměsí, s př́měsí odpadního dřeva, s př́měsí drceného polystyrenu. Př́klad použití do drátkobetonu a spojení s prutovou výztuží. [fotografie].

[5] Př́́klad demontovatelných tesařských spojů. In: LignaTool [online]. (c) 2015 LignaTool. [vid. 5.1.2015]. Dostupné z: http://www.lignatool.at

[6] Witteween architect - Casco facade - demontovatelné spoje umožňují opětovné použití celých prvků nosné konstrukce. In: architectenweb [online]. (c) 2014 architectenweb. [vid. 14.3.2014]. Dostupné z: www.architectenweb.nl 
